\title{
White Boy: Prison Life Writing and White Male Victimhood in T. J. Parsell's Fish and Jack Henry Abbott's In the Belly of the Beast
}

\section{Simon Rolston}

Most white Americans tend not to distinguish race as an important or even identifiable part of their identity. As Paula M.L. Moya and Hazel Rose Markus write in Doing Race: 21 Essays for the 21 $1^{\text {st }}$ Century (2010), "Many whites are quite comfortable with the idea that race (especially) and ethnicity are things that Asians, Latina/os, and blacks have to contend with, but that white people do not. They regard themselves as a neutral or standard, without race or ethnicity, or as a member of the 'human race." "Moreover," Moya and Markus continue, "when experimental social psychologists ask people to describe themselves on open-ended questionnaires, white people tend not to mention the racial or ethnic aspects of their identity." White racial identity, or "whiteness," is not always so invisible to white people, however. Whites at the boundaries of white normativity - such as poor whites - are unable to fully lay claim to what David Roediger, after W.E.B Du Bois, calls the "wages" of whiteness, the tacit "status and privileges" of their racial identity. ${ }^{2}$ Consequently, their whiteness (or their inability to claim a normative whiteness) is underscored, made visible, as evidenced by the epithet "white trash." As whiteness studies theorists have suggested, much can be learned about white normativity by exploring how whites at the boundaries of whiteness negotiate their distance from entitlement, performing cultural work that seeks to claim or critique an otherwise taken-forgranted racial identification. ${ }^{3}$ 
Perhaps those persons most at the boundaries of white normativity in America are incarcerated whites. They are at the "boundaries" because they are physically excluded from society, of course, through walls and razor wire, but they are at the boundaries of white normativity and the American status quo because they have lost many of the tacit "privileges" of whiteness (including many presumed rights like voting, for example). White prisoners are what Michelle Alexander in The New Jim Crow: Mass Incarceration in the Age of Colorblindness (2010) calls "collateral damage" since they have been swept up in a criminal justice system geared toward the mass incarceration and (in Alexander's terms) segregation of African American men and Latinos. ${ }^{4}$ Thus segregated, white prisoners quickly become acutely aware of their whiteness - which is otherwise an opaque racial identity for most white Americans. Identifying how the space of the prison makes whiteness intensely visible for white prisoners raises important questions for studies of prison but also for analyses of race and crime in America: How does the post-1980s criminal justice system, or what Alexander calls the "New Jim Crow," reorganize white racial formations? What cultural scripts do these prisoners use to negotiate the racially marked space of the prison where whiteness does not constitute an unspoken "common sense" that is beyond commentary or critique? And what does this imprisoned population reveal about hegemonic performances of race outside prison where emergent and residual forms of whiteness shift to account for social changes but continue to resist racial equality? ${ }^{5}$

Whiteness is frequently registered in prisoners' life writings. For example, prisoner and activist Sam Melville, who was shot to death during the infamous Attica uprising, writes in his 1972 posthumous memoir Letters from Attica, "One thing is for certain: when I emerge [from prison] . . I won't be a honky anymore." Thirty years later, Jimmy Lerner describes in his prison memoir, You Got Nothing Coming: Notes from a Prison Fish (2002), how his fellow white prisoners are "white trash," neo-Nazis, and "woods" (which is short for "peckerwoods," a self-ascribed moniker for some white prisoners), like Kansas, his cellmate, who is a white supremacist prison gang member. ${ }^{7}$ Curiously, both Melville and Kansas share an interest in redefining their white racial identities. True, Melville's hoped-for postwhite identity is clearly quite different from Kansas' hyperbolic racism. But both men speak to a phenomenon behind bars: whether rejected (like Melville) or asserted (like Kansas), whiteness is highly visible but uncharacteristically elastic in prison; whiteness loses meaning and demands redefinition behind prison walls. Despite the range of performances of whiteness in prison-from the antiracist reconfigurations of whiteness in the activism and writings of prisoners such as Sam Melville to the grotesque, hyperracist iconography, mythology, and tattoos of white supremacist prisoners like Kansas - white prison writers during the post-civil rights era of accelerated black incarceration often draw on narratives of white victimhood as they seek to redefine what whiteness means in their life writings. 
I focus my discussion of whiteness behind bars on two prison memoirs, T.J. Parsell's Fish: A Memoir of a Boy in a Man's Prison (2006) and Jack Henry Abbott's In the Belly of the Beast: Letters from Prison (1981), because they provide two different narratives about white victimhood that are characteristic of white male prison life writing and white American discourse about imprisonment. ${ }^{8}$ Moreover, these two narratives also suggest seemingly different but complementary ways that whites outside prison frame their relationship to white supremacy. Parsell's story of sexual servitude to African American prisoners dramatizes white, middle-class male anxieties about violent, so-called "reverse racism" behind bars, a paradigm that I suggest revives what Wilbur J. Cash in Mind of the South (1941) coined the southern "rape complex."" I argue that the southern rape complex's paradigm of the violent black rapist and the violated Southern belle is redirected in prison rape discourse to a paradigm of the black male rapist and the violated young white male. The black rapist/ white male victim paradigm legitimates age-old stereotypes of black male criminality that justify the incarceration of young black men in increasingly large numbers, and it stabilizes whiteness as the natural condition of free citizenship, since it implies that whiteness is fundamentally out of place in prison.

By comparison, Abbott draws attention to the broader, structural forms of oppression that incarcerate African Americans in such large numbers, framing individual experiences of sexual assault such as Parsell's as effects of socioeconomic determinates. And yet, Abbott is incapable of mounting an antiracist argument without also trying to locate himself in a position of nonwhite victimhood. Abbott identifies with African American socioeconomic privation, arguing that he too has been victimized by a hermetic middle-class white community that has similarly abused and excluded him. As I will show, however, Abbott cannot sustain his nonwhite or postwhite position because the lines of white privilege that are at work outside of the prison remain in place behind bars. Like other prison narratives of white victimhood (such as the origin story of the Aryan Brotherhood, a white supremacist prison gang supposedly created to "defend" whites against black and Latino prison gangs), Parsell's and Abbott's memoirs interlock with, and risk legitimating, a myth of white male victimhood that has been forwarded by conservative groups in response to (among other things) the advances made by various civil rights movements and feminism, the "culture wars," and neoliberal economic policies that disproportionately affected blue-collar labor over the past thirty years. ${ }^{10}$ The supposed "crisis" of white masculinity that emerged in the 1980s and has persisted as a cultural phenomenon finds legitimacy in prison narratives that represent white men as victims of race-based violence. ${ }^{11}$

If whiteness in prison is represented in popular culture or analyzed in academic work (which is rare), it is usually highly visible forms of white bigotry, such as white supremacist prison gangs, that overshadow the discussion. ${ }^{12}$ But this form of white racism always triggers intense forms of social examination largely because whites can easily distance themselves from such overt expres- 
sions of racism. However, contemporary manifestations of racial discrimination are safeguarded not by explicit expressions of racial hostility but rather by what Michelle Alexander calls "racial indifference," a "lack of compassion and caring about race and racial groups" that is maintained through the circulation of racially encoded cultural scripts such as the black beast rapist, which is realized in Parsell's book, or through the exculpation of white complicity in white supremacy, which occurs in Abbott's epistolary autobiography. ${ }^{13}$ Let me be clear, however: my study does not aim to attack Parsell's or Abbott's books as exceptional instances of racism; rather, I use their books because they are, on the whole, quite progressive in their approach to social inequalities. By focusing on progressive rather than clearly bigoted articulations of whiteness, I show how deeply pervasive problematic conceptualizations of whiteness (and blackness) happen to be in the American prison and the American imaginary.

Finally, I should note that writing about whiteness, particularly in a prison system that disenfranchises and marginalizes minorities, is ethically tricky territory. As Ruth Frankenberg writes, "if focusing on white identity and culture displaces attention to whiteness as a site of racialized privilege, its effectiveness as antiracism becomes limited." ${ }^{.14}$ Because Americans of color are grossly overrepresented in prisons, most theorists exclusively discuss what Auli Ek in Race and Masculinity in Contemporary American Prison Narratives calls "minority positions" when engaging with issues of race and imprisonment. ${ }^{15}$ Such an approach is critical and timely. And yet "white," "whiteness," and related terms such as "white supremacy" are oft-used but underexamined constructs in studies of imprisonment, maintaining the unmarked (normalized, transparent) status of whiteness, and leaving prisoners' antiracist deconstructions of whiteness and hyper-racist consolidations of whiteness out of critical focus. By exploring how the prison consolidates and perhaps also complicates white racial identity, I hope to denaturalize or deconstruct white privilege rather than displace important arguments about the prison's role in maintaining structural racism.

\section{Whiteness Visible: White Privilege, Prison Segregation, Black Criminality, and the Imprisoned White Minority}

I propose four main reasons why whites re-evaluate their racial identities in prison. First, for white prisoners, prison involves the curtailment of what whiteness theorists argue are the de facto and de jure privileges that underpin whiteness in American society. As Joy James writes in The New Abolitionists: (Neo) slave Narratives And Contemporary Prison Writings (2005), "The encoding of slavery or criminality onto blackness"-which I will discuss in a moment"reflected a counterpart construction: the inscription of 'whiteness' and nonincarceration as freedom and civility, hence as property or existential wealth."16 If whiteness is more than race, if it is, in Cheryl Harris's formulation, "race plus privilege," then whiteness is made visible after the privileges associated with it, 
as well as the socioeconomic structures that sustain its normativity, have been curtailed or removed. ${ }^{17}$

Second, American prisons have become stratified and organized by race as a result of prison policies and prisoner groupings that promote racial segregation, despite civil rights cases such as Gates v. Collier or Lee v. Washington that deemed racial segregation unconstitutional in prisons. Segregation in prisons continued despite juridical mandates in part because prisons were largely hermetic, separated from a wider society that was generally disinterested in prisoners and prisoners' rights. ${ }^{18}$ Prisons also remained segregated well into the 1970s and 1980s because segregation "was a long-held tradition in a type of institution where tradition mattered," according to Chad R. Trulson and James W. Marquart in First Available Cell: Desegregation of the Texas Prison System (2009). "A total institution like the prison relies on tradition to bring a measure of routine and predictability to an unpredictable environment filled with unpredictable individuals - according to prison administrators." ${ }^{19}$ Moreover, controlling racially motivated violence and race-based prison gangs provided many prisons with the justification for maintaining racially segregated tiers, cell blocks, or cells (as well as dining, exercise, work, and other social activities) ${ }^{20}$ As a result of ongoing racial stratification, white prisoners (and prisoners of all racial groups) were encouraged, coerced, or forced by staff, guards, and other prisoners to group themselves according to race. Although white Americans have often grouped together to the (often violent) exclusion of other races, prison segregatory practices reinforced notions of community or solidarity along explicitly racial lines.

Third, as Joy James suggests above, the subject position "prisoner" has been equated with blackness through decades of cultural, legal, legislative, and bureaucratic work that has disproportionately targeted poor black communities. Since Reconstruction, a variety of laws were established to criminalize African Americans, providing for a systemic "evolution from plantation to penitentiary." ${ }^{21}$ Scholars such as Joy James, Angela Davis, H. Bruce Franklin, and most recently Michelle Alexander note how laws such as the "Black Codes," Reconstruction-era laws that targeted African Americans for incarceration, and crack cocaine laws of the 1980s that disproportionately targeted poor black communities, equated criminality and imprisonment with black masculinity. ${ }^{22}$ As Scott Christianson writes in With Liberty for Some: 500 Years of Imprisonment in America (1998), "Notwithstanding any statistical anomalies, blacks were disproportionately imprisoned in every state [by the 1990s], and the disparity was widening fast. ${ }^{{ }^{23}}$ By 2010, according to the U.S. Department of Justice's Bureau of Justice Statistics, there are 4,347 black, 1,775 Hispanic/Latino, and 678 white inmates "held in custody in state or federal prisons or in local jails per 100,000 U.S. residents. ${ }^{.24}$ Consequently — and this is the fourth reason why whites re-evaluate their racial identities in prison - while whites may constitute a majority position in America, they are a racial minority in the American carceral system. Therefore, while many whites may experience whiteness as a 
norm rather than a racial identity outside the prison, their racial identities can no longer be experienced as "“a peripheral, non-essential reality" inside the prison. ${ }^{25}$ As T.J. Parsell writes in Fish, "For the first time, I caught a glimpse of what it must have been like for a black man, who suddenly found himself in an all-white neighborhood." 26

However, while whiteness is troubled in prison, it retains a great degree of currency in relation to the law, prison administration, staff, and guards: whites typically receive shorter sentences and earlier parole than blacks, ${ }^{27}$ whites are less likely to receive the death sentence than blacks who have committed the same crimes, ${ }^{28}$ and guards (who are typically white) have been known to establish alliances with white prisoners (as I will show with Jack Henry Abbott). White prisoners may claim that their race makes them particularly vulnerable behind bars, but they are at a significant advantage to nonwhite prisoners because the legal and prison systems, and the employees of those systems, provide them with de facto and de jure advantages and privileges. Whiteness in prison, then, functions in relation to several axes of power that produce a range of performances of what whiteness ultimately means in prison-some that question white privilege, others that try to reinvest and consolidate it.

\section{T. J. Parsell's Fish: "Pretty White Boy"}

Now that I have explained something of the dynamics of whiteness as a racial formation in post-civil rights-era prisons, I want to consider how T.J. Parsell's memoir, Fish, negotiates this shifting social and ideological territory and how it, perhaps unwittingly, relies on a trope of white victimhood that obscures the structural racism, de facto segregation, and racial exclusions that form the context for the sexual violence that Parsell experiences behind bars.

For twenty years, T.J. Parsell worked as a successful software executive. Then, in his forties, Parsell made a career-change: he began public advocacy and human rights work full-time, fighting prison rape and advocating for the rights of LGBT prisoners. He became the president of Stop Prison Rape (renamed Just Detention International) and, as a result of his advocacy work, he was invited to testify before the Bush-appointed bipartisan National Prison Rape Elimination Commission (NPREC), which was established by the Prison Rape Elimination Act of 2003. ${ }^{29}$ Fish: A Memoir of a Boy in a Man's Prison emerged organically out of Parsell's work as an activist fighting sexual assault in prisons. The book details Parsell's horrifying four-year ordeal in the Michigan carceral system. Incarcerated as a teenager for the crime of robbing a Fotomat with a toy pistol, Parsell was gang-raped on his induction to prison and subsequently owned by a black prisoner named Slide-Step who won him in a coin toss. Parsell comes to grips with his sexual identity in prison, learning to embrace his homosexuality while at the same time suffering unjustly for it, as prisoners continued to prey on him. Despite Parsell's personal story, his 
activism, and his sensitivity to different forms of discrimination in prison, his memoir reproduces a disturbingly tenacious racial myth in the white imaginary.

Fish retrofits a Reconstruction-born myth of the "black beast" bent on raping the pure, white Southern woman, a paradigm that W. J. Cash famously dubbed the southern rape complex in The Mind of the South. According to Cash, the southern woman was identified as "the very notion of the South itself." An "assault on the South," such as the Yankee invasion of southern land during the Civil War, was by extension an assault on southern women. Moreover, writes Cash, emancipation and reconstruction provided ex-slaves with the "opportunity to advance," which "inevitably opened up to the mind of every Southerner a vista at the end of which stood the overthrow of [the miscegenation] taboo": "If it was given to the black to advance at all, who could say ... that he would not one day advance the whole way and lay claim to complete equality, including, specifically, the ever crucial right of marriage?" ${ }^{30}$ Conflating interracial marriage and sex with rape, Cash's southern white men sought to defend southern white women against the threat of miscegenation and (imaginary) rape by attacking and often lynching black men. ${ }^{31}$ This "complex" engendered the paradigm of the lascivious black rapist and the innocent white southern belle that was replayed throughout reconstruction and the Jim Crow period in books such as Thomas Nelson Page's Red Rock: A Chronicle of Reconstruction (1898) and Thomas F. Dixon, Jr's The Clansman (1905), which was adapted into D. W. Griffith's film The Birth of a Nation (1915).32

As I will show through my analysis of Fish, the southern rape complex's black beast rapist and pure, innocent white woman did not disappear at the end of Jim Crow. Instead, it resurfaces in prison rape narratives as the black male rapist/white male victim paradigm that also circulates in wider discourses about prison rape (whose ubiquity in American culture is exemplified in the recent film Hit \& Run, where a white burglar describes being raped in prison and his coconspirator jokingly asks, "Was it a black guy?"). ${ }^{33}$ Furthermore, the appearance of the black beast rapist/ white victim paradigm in the work of an advocate of LGBT rights, someone who is attuned to the concerns of marginalized communities, indicates the degree to which white Americans as a group continue to understand race consistently in terms of dated and loaded stereotypes, even though those stereotypes have been mostly exorcised from acceptable discourse. Racial narratives used by whites to consolidate white supremacy, like the black beast rapist/ white victim paradigm, resurface when whites are without (or seemingly without) the trappings of white privilege and power.

Resonating with Frank Lauterbach's metaphor of the "carceral wilderness," where the prison is analogous to the otherworldly "howling wilderness" of the seventeenth-century Puritan imagination, the prison in Fish is an "inverted world" where "all the values were reversed." ${ }^{34}$ In Fish's inverted world, African Americans predominate: "There were three whites in the holding cell, not counting me," writes Parsell of his initial induction to Michigan's Wayne County Jail, "and more than twenty or thirty blacks. ${ }^{35}$ African Americans con- 
stitute a racial majority in Wayne County Jail because of the jail's proximity to Detroit, where blacks comprise a demographic majority (a detail that I will return to). The racial makeup of the jail makes Parsell intensely conscious of his whiteness: not only does he feel "smaller and skinnier" alongside the other "black, well muscled" prisoners, but he feels "paler than ever." ${ }^{36}$ Parsell, like the southern rape complex's characterization of white womanhood, is young, innocent, naive, and attractive: "I was skinny and my face was hairless," he writes. "I looked younger than seventeen. With the exception of a few zits ... my skin was smooth. ${ }^{{ }^{37}}$ Because of his age and good looks, Parsell feels threatened by the African American prisoners, as do most of the other white prisoners whom he encounters in the jail. "YYou've got to watch yourself, little bro," a white prisoner named Randy tells him. "'Your pretty blue eyes and long curly hair might be too much for these motherfuckers. They're going to want some of that fine white booty." ${ }^{38}$ As Randy's comment implies, and as Fish shows, the southern rape complex's pure white, southern womanhood and contrasting hypersexual, degenerate, lascivious black masculinity are reinscribed in white accounts of the same-sex environment of the American prison.

Initially diffuse, without any particular object, sexual violence manifests itself in prisoners' stories about a gang rape, ${ }^{39}$ a snippet of an overheard conversation between two black prisoners about a white inmate who "is fuckin'," or is sexual subservient to another prisoner or prisoners, ${ }^{40}$ and overheard comments like "That punk is gonna need a man" and "There's no bigger joy than a pretty white boy." "'41 Increasingly, Parsell senses that the other (predominantly black) prisoners are observing him, not simply sizing him up, but also assessing him as a sexual object. An African American prisoner named Moseley, for example, who "was enormous in size, well over six feet six," whose "skin was so dark it almost looked purple," and who "didn't care much for white boys," stares at Parsell repeatedly. ${ }^{42}$ Soon after Parsell notices Moseley eyeing him again, a prison psychologist asks Parsell in a private meeting, "Ever been fucked?," essentially providing a retrospective commentary on the intent behind Moseley's gaze and a prospective commentary on the sexual violence that would be wrought on Parsell's body in the prison's general population - including by Moseley, several chapters later. ${ }^{43}$

Although African American prisoners in Fish are overwhelmingly violent, lascivious, and rapacious, Slide Step, the African American man who ultimately "owns" Parsell as a result of a coin toss, initially appears to be an exception, destabilizing the black rapist-white victim paradigm. "Thank God Slide Step stepped in when he did," writes Parsell, reflecting on Slide Step's intervention when Parsell was gang raped upon arriving at Riverside Correctional Facility. "He seemed different from the others." ${ }^{44}$ Slide Step seems genuinely enamored of Parsell. "Can you handle my feelings for you?," he asks Parsell at one point. "I'm talking about caring for you." ${ }^{45}$ Slide Step treats him well by prison standards; he is "gentle," and he provides Parsell with protection from the other prisoners. ${ }^{46}$ But Slide Step effectively owns him; sex is invariably 
coercive, one-sided, unsatisfying, and ultimately nonconsensual. Moreover, as Parsell later learns from Paul, another white prisoner, Slide Step set up the initial gang-rape on Parsell's induction to the prison: “"He wanted you to come willingly into his fold, grateful to him for rescuing you. Who wants a wife that's resentful about being there? It's easier to control you that way," explains Paul. ${ }^{47}$ Slide Step exercises a kind of manipulative soft power in his relationship with Parsell, but it is by no means power without violence, and it certainly does not destabilize the white victim-black sexual aggressor paradigm of the southern rape complex that overdetermines how interconnections of sexuality, power, and race are defined in Fish.

My analysis of the southern rape complex in Fish is not meant to disregard Parsell's sexual victimhood, nor is it meant to diminish the importance of his book as what autobiography theorists call "testimonio," an autobiographical work that bears witness to or stands for the experiences of a particular group. ${ }^{48}$ Fish bravely gives voice to the experiences of many men (and women) who are sexually assaulted in jails, prisons, holding centers, and other carceral institutions. Moreover, as a coming-out story that describes the difficulties of being a gay man in prison, Parsell's book speaks on behalf of a gay community behind bars that has not had a voice in American prison life writing or in wider American life. I am also not trying to suggest that the racial paradigms of his experiences of sexual violence are somehow misleading. Instead, I am interested in the way his reproduction of those experiences in the prison life writing genre tap into a discursive formation about white victimhood and black savagery that circulates outside his story and that makes his experiences "true" to a wider (white) readership. Terry Threadgold's description of Deborah Cameron and Elizabeth Frazer's work on texts about sex-killing is instructive here: "the accounts that people give of killers, or that killers give of themselves are not the 'truth.' They are constructions, and like all constructed texts, they depend on what Cameron and Frazer call 'the codes of the culture' to give them meaning." ${ }^{49}$ Parsell's story is undoubtedly his story, but his story does not emerge exclusively from his memory of his experiences in prison. Rather, Parsell's "understanding of the events he records, like his representation of them, is always mediated" by "the codes of the culture": a "kind of coded understanding and discursive and intertextual limitation." ${ }^{50}$ In order for Parsell's horrific experiences of prison rape to be shared - particularly with a readership that likely has no firsthand knowledge of the prison-those experiences are made recognizable through an intricate webbing of cultural reference points, an intertextual circuit that limits, influences, and informs (and is ultimately informed by) his story.

Parsell likely draws on the southern rape complex, with its virginal white victim and black beast rapist, because it is a familiar paradigm for explaining prison violence in American popular culture: "Now ain't that a sad sight," Nice Guy Eddie says to his mobster father in Quentin Tarantino's Reservoir Dogs; "[he] walks into jail a white man, walks out talkin' like a nigger. It's all that 
black semen been shootin' up his butt. It's backed up into his brain and comes out of his mouth." ${ }^{11}$ Tarentino's work, as Stanley Crouch writes, is attuned to the "ethnic quirks and racial complexities" of American culture, and Nice Guy Eddie's racist, dark humor indexes how the paradigm of the black-beast-rapist and white victim is particularly common in American discourse about imprisonment. ${ }^{52}$ As John Sloop demonstrates in The Cultural Prison: Discourse, Prisoners, and Punishment (1996), one of the dominant images of African American prisoners is as nihilistically violent rapists, intent on attacking whites:

$[\mathrm{H}] \mathrm{e}$ is violent for the sake of violence alone. This prisoner is a rapist, a liar, a spoiler of white youth. Rather than struggling against a racist culture in order to preserve his heritage, he is represented as following his nature, behaving in ways that defy transformation and thus demand restraint. ${ }^{53}$

Historically, the stereotype of the violent black male has justified different modes of "restraint." "Free blacks were often characterized as degraded, vicious, and depraved, supporting the rationale that blacks must be contained within the institution of slavery," writes Jane Rhodes. ${ }^{54}$ More recently, writes Dorothea Roberts, the "stereotype of the aggressive, 'macho' Black male legitimates the massive incarceration of young Black men." ${ }^{55}$ Cultural figures like Willie Horton, an African American rapist and murderer whose image was used by George H.W. Bush to discredit Michael Dukakis in the 1988 presidential campaign, continue to have significant cultural heft because they illuminate broadly held beliefs about black criminality that are often expressed more indirectly.

Not only does Fish draw on racialized images of black criminality that circulate in popular culture, but it also reduces instances of violence and dispossession to Parsell's story, displacing wider structural and institutional forms of racism that disproportionately harm African Americans and privilege whites. It is ultimately the wider story of redlining, racial profiling, and racial barriers to employment in Detroit that set the stage for the race-based "get-back" that is horrifically acted out on Parsell's body. This is not to suggest that Parsell ignores racism and white privilege, necessarily. He notes, for example, how his small, hometown of Dearborn had an unofficial slogan: "Keep Dearborn White." He describes the wasteland feel of "mostly black" downtown Detroit, which "never seemed to recover" from the 1960s race riots. He even describes how "whites had moved [out of the city] to the suburbs, where it was thought to be safe, and predominantly white. ${ }^{56}$ But these details are at the margins of his story, barely influencing or informing how individual acts of violence are themselves effects of destructive government, corporate, and white supremacist reorganizations of racialized bodies in space, such as white flight. ${ }^{57}$ His victimization remains separate from the socioeconomic victimization of African 
Americans, for example, despite his occasional descriptions of the local spatial politics of race and racism.

Parsell's story, however traumatic, privatizes a broader narrative of social exploitation that, sadly, results in his victimization. This is not to excuse the violence of his assailants. Rather, it is to suggest that the black men who rape Parsell are responding to the "material advantages accorded to whiteness as an economic privilege" inasmuch as they are seeking to violate him. ${ }^{58}$ Nathan McCall, in Makes Me Wanna Holler: A Young Black Man in America (1994), describes a similar racially motivated attack on a white man that, while noviolent, nonetheless speaks to the motivations of the African American rapists in Parsell's book. McCall describes African American prisoners intimidating a middle-class, middle-aged white man imprisoned in a Chicago jail as "taking a rare chance to strike back at somebody who represented the very system that made [their lives] hell." "I suspected he felt indicted by his whiteness as never before," writes McCall, "and I hoped he felt at that moment the same way I'd felt for much of my life: like an alien in a hostile world where he couldn't win; like the victim of recurring injustices against which there were no appeals." ${ }^{\circ 9}$ As McCall suggests, it is the man's complicity in white supremacy more so than his personal vulnerability that makes him an appropriate target. Moreover, as Andrew Sargent writes, there is a "cause-and-effect relationship between the privileged racial position of whiteness in the institutional hierarchy of the criminal justice system (cause) and the sexual victimization of the 'minority' white male prisoners in the jail (effect). ${ }^{960}$ In Fish, though, injury is private rather than an effect of a social system; it is narrowed to the predatory behavior of (predominantly black) prisoners who violate an injured, white body.

Parsell's likely unintentional use of the southern rape complex is imbricated in a much larger discourse about white-black relations in America, where age-old myths of white victimhood are conserved, reactivated, and expressed in oblique ways that "fue[1] a discourse that demonizes people of color for being victimized ... while hiding the privileges of whiteness." ${ }^{\prime 1}$ Fish interlocks with stories of wounded white men used to shore up claims that white masculinity is in crisis; it reveals how close to the surface racial stereotypes really are; and it demonstrates how easily those stereotypes can be resurrected by whites - even by whites who are aware of the problems of social marginalization, such as Parsell—when more nuanced narratives of whiteness are unavailable.

\section{Jack Henry Abbott: The White Negro Problem}

While Parsell's Fish ignores the sociohistorical dimensions of racial violence that play a determining role in the brutality enacted on his body (from slavery to redlining, for example), and thus obscures white supremacy, Jack Henry Abbott's In the Belly of the Beast acknowledges structural racism and critiques white privilege. However, Abbott, who is white, claims that he is not a beneficiary but a victim of white privilege, much like African Americans. Ul- 
timately, Abbott cannot articulate an antiracist position while also acknowledging his ineluctable complicity in white supremacy. Like many white liberals, he is unable to be both a beneficiary of white privilege and someone who seeks to deconstruct it.

Before discussing In the Belly of the Beast and white victimhood, I want to provide a brief overview of the book's strange and tragic publication history. In 1977, when Norman Mailer was in the midst of writing a biography of a convicted murderer named Gary Gilmore (which was to become The Executioner's Song in 1979), Mailer received an unusual letter from a prisoner named Jack H. Abbott. Abbott, who had served time with Gilmore, offered to provide Mailer with insight into Gilmore's life as a long-term convict - things only another long-term convict like Abbott could know. Abbott explained that, like Gilmore, he had been raised in incarceration: from state institutions such as reform schools to juvenile institutions to jails to prisons to maximum security and long stints in solitary confinement: Abbott knew prisons. Mailer was so struck by the intensity and skill of Abbott's letters that he responded, spawning a two-year letter-writing dialogue between the two men. With the help of a young editor at Random House named Erroll McDonald, the letters eventually developed into Abbott's epistolary autobiography, In the Belly of the Beast.

Abbott's book was published six weeks after he was paroled from prison. Although there is some debate about the amount of influence Norman Mailer had in ensuring Abbott's parole, ${ }^{62}$ Mailer did promise to provide him with work and income in New York, conditions crucial to satisfying the parole board and ensuring Abbott's early release. The night before his book was published to rave reviews - most notably by Terrence Des Pres in the New York Times-Abbott and two friends stopped for a late-night meal at The Binibon café on the Lower East Side of Manhattan..$^{63}$ Abbott got into a disagreement with Richard Adan, the night manager of the café, that quickly escalated into an argument; the argument was taken outside; and, moments later, Richard Adan was dead on the sidewalk: Abbott had stabbed him, once, clean through the heart. After several months on the run, Abbott was finally apprehended and tried for murder. He was found guilty of manslaughter and sentenced to fifteen years to life in prison. In prison, Abbott published another book in 2001 called My Return (coauthored with Naomi Zack), in which he attempted to explain his role in the murder by way of a Grecian tragedy made up of dialogue from the actual trial. (My Return is a strange piece of work: both Abbott and Adan are characters in the play, the characters re-enact the murder, and Abbott includes appendices of his own sketches of the stabbing as stage directions and supporting evidence.) A year later, Abbott was dead in his cell. An inquest concluded that he had hanged himself with a bedsheet and a shoelace.

Since the Adan murder, Abbott's memoir has been tied too closely to Norman Mailer, obscuring the racial politics of Abbott's work. In particular, it has become common to define Abbott as a mere reflection of the nihilistic hipster that Mailer celebrates in his infamous essay, "The White Negro." ${ }^{164}$ Carl 
Rollyson writes, "The vehemence of Abbott's expressions, literally underlined in nearly every page of his prose, delineates a view of repressive society that Mailer had held in 'The White Negro." "65 Likewise, Mary V. Dearborn argues that while it might not be fair to "hold Mailer to the standards he promoted more than twenty years earlier, it's hard to distinguish the long-term convict from the hipster of 'The White Negro' taken to extremes." ${ }^{\text {"66 }}$ There seems to be a desire, prevalent even among meticulous biographers such as Rollyson and Dearborn, to define Abbott as a creation of Mailer's - as a living (killing) consequence of the writer's earlier ideas. ${ }^{67}$

At first glance, Abbott seems like a Mailerian hipster in extremis, a "philosophical psychopath" hell-bent on rejecting the "square" "totalitarian tissues of American society." ${ }^{\prime 68}$ But unlike the nihilistic hipster, who has no political purpose, Abbott's often-violent diatribes against American society are informed by the black power movement's use of and interest in Marxist theory, Third World revolutionary struggles, and racial solidarity movements that emerged in prisons across the country in the 1960s and 1970s that culminated in the Attica uprising. ${ }^{69}$ In particular, Abbott's "racechanges"- to borrow a term from Susan Gubar-are influenced by proto-Marxist, antiracist revolutionary writers of his age, including prisoners such as George Jackson and Sam Melville, to whom his book is partly dedicated. ${ }^{70}$ Attributing Abbott's philosophy to Mailer thus obscures the centrality of a very different ideology that was central to Abbott's thinking, one closely aligned with a form of anti-racism that is perhaps best expressed in Sam Melville's desire not to "be a honky anymore" (see above). Melville articulates a form of postwhiteness that appeals to Abbott, who seeks a similarly effaced whiteness in his memoir, arguing that he "never had much in common with [white people]."ㄱ1 In order to dramatize his outsider-status, his difference from "white people," Abbott provides a short series of scenes that he claims occurred during his brief stint outside prison where he travels to the South and acts as an observer of state-sanctioned white supremacy and a sympathetic witness of black victimization.

On the whole, these scenes are familiar, almost clichéd settings of civil rights struggles: a segregated movie, lunch counter, and a school dance. ${ }^{72} \mathrm{Ab}-$ bott dramatizes how he is unaccustomed to the racism of white supremacist America, often blundering into white segregatory practices by accident. In one scene, for example, Abbott watches while white police officers shoot and kill an innocent black farmer over a parking infraction as the man's son watches, horrified. ${ }^{73}$ Abbott freezes, appalled "because [he] could not believe what he was seeing." ${ }^{.74}$ In this scene, Abbott reproduces a familiar triangulation in postcivil rights representations of violent white supremacy: the violent white racists (here, represented by the police and members of the southern white community), the black subject(s) in pain (with a focus on the brutalization of a black body), and the sympathetic, morally tortured white witness (Abbott). This triangulation drives a wedge between Abbott and white supremacy, a wedge that reappears in what Mark Golub calls "Hollywood redemption history" dramas 
about slavery or Jim Crow-such as Mississippi Burning, The Long Walk Home, Amistad, and Glory - where the "point of identification character [with whom the audience is expected to identify] is a charismatic white man [or woman, as in The Long Walk Home,] who fights (or comes to fight) against oppression." 75 The triangulation that I identify, and the genre that Golub brackets, provide whites with a location from which they can view racism from a morally safe distance and divest themselves of their potential complicity in white supremacy, despite the fact that white supremacy in the post-civil rights-era is usually maintained without blatant expressions of racial discrimination let alone overt demonstrations of racial violence.

Through these scenes, Abbott dramatizes what he means by "white people": "white people who are in a position to commit these racial injustices." claims that he is unable (let alone unwilling) to participate in white oppression and wield white privilege. For Abbott, his difference from white people is classbased. He claims to "shar[e] a common oppression" with African Americans because he is poor, even asserting that "class oppression and racial oppression are identical." ${ }^{\prime 77}$ Claiming that poor whites are at an equal disadvantage to blacks risks occluding how whites, regardless of their antiracist intentions or socioeconomic status, invariably receive the benefits that underpin white identity, simply by being white in America. As Abbott himself demonstrates, even poor whites benefit from the racial caste system at work in American society, including in the criminal justice system. For example, Abbott describes how guards interpellate his whiteness, suggesting its fraternal possibilities for him, its currency even when he is celled with disproportionately black prisoners: "We're white men like you," a white guard tells him. "Those blacks don't like you any more than they like us." ${ }^{778}$ Regardless of his economic status, Abbott is not in a position of innocence or unaccountability in relation to white supremacy. As the guards suggest, Abbott cannot shrug off whiteness despite his experiences of socioeconomic privation, his distance from a normative "bourgeois" whiteness. "If the pigs would approach me like that," he writes, underscoring the lines of racial complicity in the prison system, "I know they must do it to the other white prisoners." from the deployments of white supremacy and refunctioned as cross-race and cross-class struggle." 80 In the Belly of the Beast, always enigmatic and often paradoxical, thus asserts and subverts a postracial whiteness. Abbott claims a fundamental difference from white people while also perhaps acknowledging that he is ineluctably white, despite his best intentions.

This paradoxical position reasserts itself in the same chapter, when Abbott describes an instance of race-based aggression outside an all-white dance in Salt Lake City. Abbott is attacked by "[s]ix or seven blacks about [his] age," presumably in retaliation for being excluded from participating in the nearby dance on account of their race. ${ }^{81}$ Abbott comes to a very different conclusion about this instance of race-based violence than Parsell does when he reflects on his experiences of victimization: "Today I realize I have had to pay the price 
many times for the social injustices committed by white people in this society." ${ }^{82}$ However, Abbott tries to make this observation from a position exterior to whiteness. The black youth are responding to those "white people," argues Abbott, and their violence is supposed to "force [him] into the ranks of white society," which he resists. ${ }^{83}$ As Robyn Wiegman observes, "The desire to combat white privilege seems unable to generate a political project against racism articulated from the site of whiteness itself." Abbott's constitution of himself as what Wiegman calls an "antiracist subject," then, occurs only after he has performed the intellectual contortions of divesting himself of his own whiteness. ${ }^{84}$ Only by disaffiliating himself from "white people" can he mount an effective critique of white supremacy. As Wiegman argues, "Disaffiliation from white supremacy founds contemporary white identity." ${ }^{85}$ This "liberal whiteness" resuscitates the American narrative of democratic progress by representing racism and white supremacy largely in articulations of virulent, explicit racism (the George Wallaces, the David Dukes, and the Ku Klux Klan), while (for the most part) neglecting the ongoing institutional racism (in the criminal justice system, for example) that cuts against the grain of an American story of racial and social uplift.

Yet the black youth who attacked Abbott are clearly responding to existing forms of structural racism that are harder to resist (such as a segregated dancehall) but that they know privilege Abbott because of his skin color. "While they were hitting me," writes Abbott, "one kept yelling something about not being able to dance." ${ }^{" 86}$ Their attack establishes his proximity to white dominance even as he tries to deny "accountability and historical connection" to white systems of oppression, as bell hooks suggests postwhite liberalism often seeks to do ${ }^{87}$ Abbott's desire to distance himself from "white people" is always in tension with his inability to entirely do so, as other people - white guards and black teenagers - remind him that he cannot divest himself of the whiteness that he eagerly seeks to reject.

Thus In the Belly of the Beast dramatizes a tension between an idealized postracial subject-a white identity without what Hamilton Carroll calls the "stigma of privilege" - and a white subject who, antiracist sentiments aside, cannot be unyoked from white power structures through the exercise of individual agency. ${ }^{88}$ If Abbott's rejection of his own whiteness cleaves with arguments amongst some theorists that whiteness can and should be "abolished," his inability to fully realize that project despite his best intentions reflects the shortcomings of a white-abolitionist position. ${ }^{89}$ Moreover, Abbott's hoped-for non-whiteness turns on an argument that is also made by white men who feel as though they have been the victims of "reverse discrimination" (an argument forwarded by the affirmative action "backlash," for example): he has not created white privilege or minority disempowerment (or benefit from either) so the "stigma" of whiteness is not his responsibility. He has nothing "in common" with "white people who are in a position to commit these racial injustices." Abbott shows that the unintended consequences of a white abolitionist argument 
is to articulate a variation on the commonly held belief among whites that they are race neutral or raceless and to venture into the field of colorblindness that conservatives have occupied since the post-civil rights era as a way to claw back gains made by civil rights legislation, such as affirmative action.

\section{Conclusion: Prison Life Writing and the Discourse of White Victimhood}

In the Belly of the Beast provides a kind of commentary on Parsell's experiences of race-based violence in the prison. Abbott writes that he is "aware of white boys being raped and murdered in prisons," but such violence is "justified socially." ${ }^{90}$ While Abbott's logic is unnecessarily harsh (his assertions of widescale black violence are also characteristically hyperbolic), and while such violence is never "justified," he correctly foregrounds the social implications of individual acts of violence, framing white victimhood in the prison as an effect of broader, social oppression - much as his beating outside the all-white dance was a response to segregation and his invariable participation in it as a white man. As George Lipsitz argues, "As long as we define social life as the sum total of conscious and deliberate individual activities, then only individual manifestations of personal prejudice and hostility will be seen as racist. . . . Collective exercises of group power relentlessly channeling rewards, resources, and opportunities from one group to another will not appear to be 'racist' from this perspective because they rarely announce their intention to discriminate against individuals. But they work to construct racial identities by giving people of different races vastly different life chances." "91 The exclusive focus on the violation of Parsell's body in Fish eclipses the role that broad, structural forms of racial discrimination likely played in his rape. Abbott's Belly, by comparison, suggests that stories of individual white powerlessness in the prison often obscure the degree to which the very source of white victimhood - racial disparity in prison populations - is an effect of a broader, social victimization of minorities, particularly African Americans. "Racialized mass incarceration," as Lawrence Bobo and Victor Thompson describe the targeted imprisonment of young men from poor black communities, paradoxically becomes the condition for white disempowerment if victimhood is narrowed to the experience of the white autobiographer alone.

That said, both Parsell and Abbott employ narratives of white victimhood to explain their experiences as white men behind bars to other, nonimprisoned whites (who constitute the majority of their readership), narratives that potentially feed into a discourse of white male victimization and "crisis" in America. Many heterosexual white men have developed a discourse of victimization since the 1980s in response to perceived social and economic threats to their authority and unquestioned racial/sexual/gendered normativity. Curiously, while Parsell's story speaks on behalf of a community that heterosexual white males feel has contributed to their sense of crisis, his memoir also realizes a variation 
of that crisis where white masculinity (the majority) is attacked by a threatening minority. Abbott's sense of his own victimization suggests whites' ongoing difficulty with articulating antiracist positions while also acknowledging their inevitable, complicity in white supremacy. Ultimately, Parsell's and Abbott's stories are in jeopardy of materializing and thus legitimating a discourse of white male crisis, investing a generalized, fictional emergency with individualized truth, even as white masculinity continues to consolidate its power. Racialized narratives of white victimhood in their multivalent forms, from the southern rape complex to a postracial subject that seeks to slough off the appearance (if not the substance) of white privilege in order to claim a position of comparative victimhood, risk reentrenching social and economic hierarchies along racial lines.

\section{Notes}

1. Paula M.L. Moya and Hazel Rose Markus, Doing Race: 21 Essays for the $21^{\text {st }}$ Century (New York: W.W. Norton \& Co, 2010), 11.

2. David Roediger, The Wages of Whiteness: Race and the Making of the American Working Class (London \& New York: Verso, 1991), 12.

3. For an analysis of whiteness using the methodological tools of "boundary theory," see Matt Wray, Not Quite White: White Trash and the Boundaries of Whiteness (Durham: Duke University Press, 2006), or Annalee Newitz and Matt Wray, eds. White Trash: Race and Class in America (New York: Routledge, 1997).

4. Michele Alexander, The New Jim Crow: Mass Incarceration in the Age of Colorblindness (New York: New Press, 2010), 199.

5. For more on the making of whiteness as a normalized and thus invisible racial category in American literature and culture, see Valerie Babb, Whiteness Visible: The Meaning of Whiteness in American Literature and Culture (New York: New York University Press, 1998). I use Raymond Williams' theories of "emergent" and "residual" cultures here because they help signpost how whiteness is historically contingent. For instance, my analysis of Parsell's Fish unearths a "residual" form of whiteness that bears traces of explicit forms of racism that had particular force during reconstruction but clearly continue to hold a form of cultural authority for white people, even if only at a "preconscious" level in American culture. And my analysis of Abbott's Belly (which was, of course, published over twenty years before Fish) reveals an "emergent" form of whiteness that on the surface seems to reject racism but in fact benefits from white supremacy. Raymond Williams, Marxism and Literature (Oxford: Oxford University Press, 1977).

6. Sam Melville, Letters from Attica (New York: Morrow, 1972), 57.

7. Jimmy Lerner, You Got Nothing Coming: Notes from a Prison Fish (New York: Broadway Books, 2002).

8. T.J. Parsell, Fish: A Memoir of a Boy in a Man's Prison (New York: Carroll\& Graf, 2006); Jack Henry Abbott, In the Belly of the Beast: Letters from Prison (New York: Vintage Books, 1982).

9. Wilbur J. Cash, The Mind of the South (New York: Vintage Books, 1960).

10. For more on the discourse of white male crisis, see David Savran, Taking it Like a Man: White Masculinity, Masochism, and Contemporary American Culture (Princeton, NJ: Princeton University Press, 1998).

11. This plank of my argument cleaves with Andrew Sargent's claim that prisons are often represented as problematic in American culture "not because of the damage they do to African American men and minority communities, but rather because of the bodily destruction they may cause to white men unlucky enough to be incarcerated." Andrew Sargent, "Representing Prison Rape: Race, Masculinity, and Incarceration in Donald Goines's White Man's Justice, Black Man's Grief," MELUS 35, Number 3 (2010), 132.

12. In popular culture, whiteness in prison is almost inevitably discussed in terms of white supremacist prison gangs: The National Geographic Channel's documentary "Aryan Brotherhood"; television characters like Vernon Schillinger in HBO's $O Z$; or more recently, the fictional "Alliance for Purity" white supremacist prison gang in the wildly popular television series Prison Break. Critical analyses of whiteness in prison, when they occur, also tend to analyze extreme forms of whiteness behind bars, as in "The Contradictions of 'Documentary Realism' in American History $X$," the fifth chapter in Peter Caster's excellent study, Prisons, Race, and Masculinity in TwentiethCentury U.S. Literature and Film (2008). 
13. Alexander, The New Jim Crow, 198.

14. Ruth Frankenberg, "Introduction: Local Whiteness, Localizing Whiteness," in Displacing Whiteness: Essays in Social and Cultural Criticism, ed. Ruth Frankenberg (Durham: Duke University Press, 1999), 17.

15. Auli Ek, Race and Masculinity in Contemporary American Prison Narratives (New York: Routledge, 2005), 11.

16. Joy James, The New Abolitionists: (Neo)slave Narratives And Contemporary Prison Writings (Albany: State University of New York Press, 2005), xxv.

17. Cheryl Harris, "Whiteness as Property," Critical Race Theory: The Key Writings that Formed the Movement. eds. Kimberlé Crenshaw et al. (New York: The New Press, 1995), 283.

18. Some Americans like those on the "radical Left" took a special interest in prisoners' rights, however, particularly during the 1970s. For more on the relationship between leftist organizations and the prison resistance movement, see Eric Cummins, The Rise and Fall of California's Radical Prison Movement (Stanford: Stanford University Press, 1994).

19. Chad R. Trulson and James W. Marquart, First Available Cell: Desegregation of the Texas Prison System (Austin, Tex.: University of Texas Press, 2009), 65.

20. Christian Parenti, Lockdown America: Police and Prisons in the Age of Crisis (New York: Verso, 1999), 171-172; Auli Ek, Race and Masculinity, 88.

21. H. Bruce Franklin, "Introduction," Prison Writing in $20^{\text {th }}$-Century America, ed. H. Bruce Franklin (New York: Penguin, 1998), 8.

22. Joy James, The New Abolitionists; Angela Davis, "From the Convict Lease System to the Super-Max Prison," States of Confinement: Policing, Detention, and Prisons, ed. Joy James (New York: St. Martin's Press, 2000); H. Bruce Franklin, "Introduction"; Michelle Alexander, The New Jim Crow.

23. Scott Christianson, With Liberty for Some: 500 Years of Imprisonment in America (Boston: Northeastern University Press, 1998), 280.

24. United States Bureau of Justice Statistics, "Correctional Population in the United States, 2010," Bureau of Justice Statistics, December 2011, 8 bjs.ojp.usdoj.gov/content/pub/pdf/cpus 10. $p d f$ (Accessed on August 1, 2012). Because of the overrepresentation of African Americans behind bars, prisons became important sites of resistance in the black power movement of the late 1960s and 1970s. Famed prison writer (and actor) Edward Bunker argues that the black power movement forced whites to take racist positions. He writes that white guards who were "secret bigots" became "outright racists" as a result of racial tensions that he claims were exacerbated by the black power movement in prison. Moreover, according to Bunker, "white convicts also resented being referred to as neo-Nazis and white supremacists . . . there was [now] so much racial paranoia that provocation was unnecessary to evoke murder."' Edward Bunker, Education of a Felon: A Memoir (New York: St. Martin's Griffin, 2000), 276. Although it is true that black power affected the racial climate behind bars (particularly in California, where Bunker was incarcerated), it is unfair to claim that the black power movement caused racial tensions (particularly the racism of white guards). Black power was influential in prison because of the existing disempowerment of and violence against black prisoners. Black power was, first and foremost, a defensive movement in prison.

25. Bob Blauner, "Talking Past one Another: Black and White Languages of Race," The American Prospect, 10 (1992).

26. Parsell, Fish, 27.

27. Dennis Shranz and Jerry McElroy et al., Reducing Racial Disparity in the Criminal Justice System: A Manual for Practitioners and Policymakers (Washington, D.C.: The Sentencing Project, 2000).

28. David Baldus and George Woodworth, "Racial Discrimination and the Death Penalty in the Post-Furman Era: An Empirical and Legal Overview, with Recent Findings from Philadelphia," Cornell Law Review 83 (1998).

29. For an account of the NPREC and Parsell's testimony, see Carolyn Marshall, "Panel on Prison Rape Hears Victims' Chilling Accounts," New York Times, August 20, 2005 http://www.nytimes.com/2005/08/20/politics/20rape.html? r=2\&pagewanted=all\&oref=slogin. For an example of Parsell's advocacy as a public figure, see his T.J. Parsell, "Unsafe Behind Bars," New York Times, September 18, 2005 http://www.nytimes.com/2005/09/18/opinion/nyregionopinions/18LIparsell. html?pagewanted=print.

30. Cash, The Mind of the South, 116.

31. For an excellent study of lynching, see Leon F. Litwack, "Hellhounds," in Without Sanctuary: Lynching Photography in America, ed. James Allen (Santa Fe, NM: Twin Palms, 2000), 8-37.

32. Thomas Nelson Page, Red Rock: A Chronicle of Reconstruction (New York: Charles Scribner's Sons, 1898); Thomas F. Dixon, Jr., The Clansman (London: William Heinemann, 1918); The Birth of a Nation, directed by D. W. Griffith (1915; David W. Griffith Corp), DVD.

33. Hit and Run, directed by David Palmer and Dax Shepard (2012; Primate Pictures), Film. 
34. Frank Lauterbach, "Textual Errands into the Carceral Wilderness: Prison Autobiographies and the Construction of Cultural Hegemonies" in In the Grip of the Law: Trials, Prisons, and the Space Between. ed. Monika Fludernik and Greta Olson (Frankfurt: Peter Lang, 2004), 26, 27.

35. Parsell, Fish, 28.

36. Ibid., 27.

37. Ibid., 42.

38. Ibid., 50

39. Ibid., 29 ,

40. Ibid, 46 .

41. Ibid., 54 .

42. Ibid., 46,60 .

43. Ibid., 60

44. Ibid., 97.

45. Ibid., 112 .

46. Ibid., 115 .

47. Ibid., 265.

48. For more on testimonio, see John Beverley, Testimonio: On the Politics of Truth (Minneapolis: University of Minnesota Press, 2004).

49. Terry Threadgold, "Black Man, White Woman, Irresistible Impulse: Media, Law and Literature Making the Black Murderer," in Thinking Through the Body of the Law ed. Pheng Cheah, David Fraser, and Judith Grbich (Washington Square, N.Y.: New York University Press, 1996), 167.

50. Ibid.

51. Quentin Tarantino, Reservoir Dogs (New York: Grove Press, 2000), 51.

52. Stanley Crouch, "Eggplant Blues: The Miscegenated Cinema of Quentin Tarantino," Reservoir Dogs (New York: Grove Press, 2000), ix. As Susan Faludi reminds us, the sexualization of the black male prisoner is a form of cultural common sense. In Stiffed, Faludi describes how an African American bodybuilder named Kerwin Scott worked briefly as an exotic dancer in a bar called "The Cell Block," where he was supposed to dress like a prisoner and dance in a makeshift prison cell. Susan Faludi, Stiffed: The Betrayal of the American Man (New York: W. Morrow and Co., 1999), 497-498.

53. John M. Sloop, The Cultural Prison: Discourse, Prisoners, and Punishment (Tuscaloosa: University of Alabama Press, 1996), 16.

54. Jane Rhodes, Framing the Black Panthers: The Spectacular Rise of a Black Power Icon (New York: New Press, 2007), 32.

55. Dorothea E. Roberts, “Deviance, Resistance, and Love," Utah Law Review (1994): 179.

56. Parsell, Fish, 7.

57. For more on the geopolitics of race and white flight in Detroit, see Thomas J. Sugrue, The Origins of the Urban Crisis: Race and Inequality in Postwar Detroit (Princeton, N.J.: Princeton University Press, 1996), or Reynolds Farley, Sheldon Danziger, and Harry Holzer, Detroit Divided (New York: Russell Sage Foundation, 2000).

58. Robyn Wiegman, "Whiteness Studies and the Paradox of Particularity," Boundary 226 , no. 3 (1999), 131.

59. Nathan McCall, Makes Me Wanna Holler: A Young Black Man in America (New York: Vintage Books, 1994), 162.

60. Andrew Sargent, "Representing Prison Rape: Race, Masculinity, and Incarceration in Donald Goines's White Man's Justice, Black Man's Grief," MELUS 35, no. 3 (2010): 139.

61. George Lipsitz, The Possessive Investment in Whiteness: Racialized Social Democracy and the 'White' Problem in American Studies," American Quarterly, 47, no. 3 (1995): 379.

62. In My Return, Abbott contends that "Mailer's letter [to the parole board] did not result in [his] parole." Mailer certainly did play a role in Abbott's early release; but it is also quite likely that Abbott would have been released anyway, since he was due (even, past-due) for parole. Jack Henry Abbott and Naomi Zack, My Return (Buffalo, NY: Prometheus Books), 1987.

63. Terrence Des Pres, "A Child of the State," Rev. of In the Belly of the Beast, by Jack Henry Abbott. New York Times. 19 Jul. 1981: BR1.

64. Norman Mailer, "The White Negro," The Long Patrol: 25 Years of Writing from the Work of Norman Mailer, ed. Robert F. Lucid (New York: World Publishing, 1971), 209-228.

65. Carl Rollyson, The Lives of Norman Mailer: A Biography (New York: Paragon House, 1991), 305.

66. Mary V. Dearborn, Mailer: A Biography (Boston: Houghton Mifflin, 1999), 357.

67. In a September, 1981 front-page article in the New York Times Book Review that was printed in reaction to Richard Adan's murder, Michiko Kakutani also suggests that Abbott modeled himself on Mailer's writings. She emphasizes Mailer's fictional characters rather than the "white negro," however: "Like Lieutenant Hearn in 'The Naked and the Dead,' Mr. Abbott asserted his own identity in the face of an arbitrary system of officially regulated morality; like Sergius O'Shaugnessy in 'The Deer Park,' he was self-educated and self-made; like Stephen Rojack in 'An American Dream,' he had killed without apology." Kakutani overstates her case here, particularly 


\section{Simon Rolston}

because she obliquely suggests that Mailer is also somehow responsible for Adan's murder since she describes Abbott, like Frankenstein's monster, as a composite of Mailer's fictional creations. Michiko Kakutani, "The Strange Case of the Writer and the Criminal," The New York Times. 20 Sep. 1981: BR1.

68. Mailer, "White Negro," 214, 211.

69 Of course, Eldridge Cleaver sees "The White Negro" as a trenchant critique of racial dynamics in America since the essay reveals "the big white lies that compose the monolithic myth of White Supremacy/Black Inferiority." However, the figure of the hipster, as Mailer describes him, deliberately shuns political movements in any meaningful way, prefers to indulge his own desires rather than come to the aid of others, and stands aloof from society. He borrows what Mailer sees as African American style more than the substance of social justice issues or civil rights. Eldridge Cleaver, Soul on Ice. (New York: Delta Paperbacks, 1999), 124.

70. Susan Gubar defines racechanges as the intentional transgression of racial boundaries, whether to parody the other (like blackface minstrelsy) or to "learn about the other by being the other," " as Deavere Smith suggests. Susan Gubar, Racechanges: White Skin, Black Face in American Culture (New York: Oxford University Press, 1997), xxi.

71. Abbott, In the Belly of the Beast, 176.

72. Ibid., 171, 173-175, 175-176.

73. Ibid., 171-173.

74. Ibid., 172.

75. Mark Golub, "History Died for Our Sins: Guilt and Responsibility in Hollywood Redemption Histories," Journal of American Culture 21, no. 3 (1998): 23.

76. Abbott, In the Belly of the Beast, 176.

77. Ibid., 182. For a discussion of the class paradigm of race, see Michael Omi and Howard Winant, Racial Formation in the United States: From the 1960s to the 1980s (New York: Routledge \& Kegan Paul,1986), 24-35.

78. Abbott, In the Belly of the Beast, 183.

79. Ibid.

80. Wiegman, "Whiteness Studies and the Paradox of Particularity," 123.

81. Abbott, In the Belly of the Beast, 175 .

82. Ibid., 176.

83. Ibid.

84. Wiegman, "Whiteness Studies and the Paradox of Particularity," 139.

85. Ibid., 121 .

86. Abbott, In the Belly of the Beast, 176.

87. bell hooks, Black Looks: Race and Representation (Boston, MA: South End Press, 1992), 25

88. Hamilton Carroll, Affirmative Reaction: New Formations of White Masculinity (Durham \& London: Duke University Press, 2011), 21.

89. For more on the white abolitionist argument, see David Roediger, Towards the Abolition of Whiteness: Essays on Race, Politics, and Working Class History (London \& New York: Verso, 1994), or Noel Ignatiev and John Garvey, Race Traitor (New York: Routledge, 1996).

90. Abbott, In the Belly of the Beast, 177. Abbott's emphasis.

91. Lipsitz, "The Possessive Investment in Whiteness," 381. 